\title{
Latin American Monetarism in Crisis
}

\section{David Felix}

Monetarism is a protean concept. While intended to be universally applicable to all capitalist market economies, the specific forms of its theoretical constructs and the content of its policy sets have varied over time and between countries. The currently dominant brand associated with Milton Friedman and the post-World War II Chicago School, differs in a number of theoretical respects from the 1930s Chicago School of Monetarism |Ascheim and Tavlas 1979:167-83]. American monetarists rationalise the failure of Mrs Thatcher's monetarist strategy for Britain as correct policy poorly executed. Until the roof caved in in 1980-81 on the monetarist strategy of Martinez de $\mathrm{Hoz}$, Argentine monetarists confidently attributed the earlier demise of Brazilian monetarism to opportunistic backsliding. Martinez de $\mathrm{Hoz}$ remained relatively steadfast to the end, hence Chilean monetarists attribute that dismal end to timing errors, to his trying to squeeze domestic liquidity and dismantle the public sector and import controls gradually rather than by 'shock treatment', Chilean style. At the time of writing [September 1981] Chilean monetarism is probably entering its crisis. Would this be the ultimate test that will corner Latin American monetarism and force eschatological mea culpas from its dying lips? Not likely. Too much ideology underlies the addiction to monetarism for that.

Like most big theories in the social sciences, monetarism is an uneasy blend of positive theorising and ideological predilections. The flexibility of monetarism reflects reinterpretations of some of its basic theoretical tenets to account for failures in application and for changing institutional circumstances. The reluctance to scrap the tenets is mainly grounded in the ideological predilections.

The basic accounting identity of monetarism, MV $\equiv \mathrm{PT}$, enables one summarily to identify its core tenets. These are:

1. M, the money supply, is a measurable entity of relatively stable composition through time.

2. The aggregate demand for $M$ is a stable measurable function, primarily of income and of expectations about the future price level.

3. Variations of $V$ (velocity) are therefore minor when the households and businesses of the economy agree with confidence on the future rate of change of the price level.

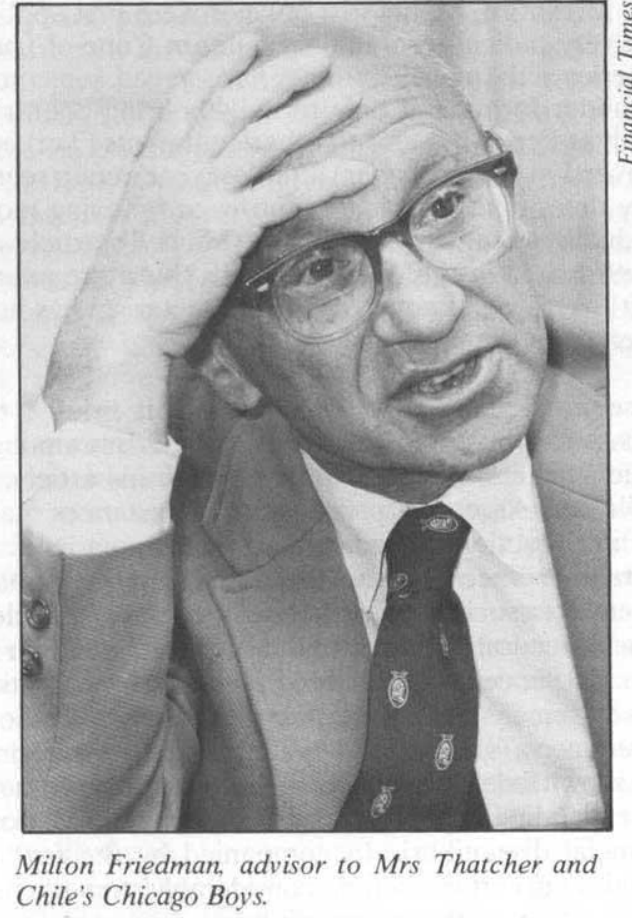

4. The private sector is inherently stable. That is, the self-correcting power of competitive market forces if allowed to operate freely tends to sustain full employment of labour and productive capacity, so that short-term oscillations of $T$ (an index of aggregate output) are narrowly bounded, while the long-term trend of $T$ is determined by the growth of the supply of labour and the technological and capital accumulating factors governing its productivity. Since $T$ is a changing aggregate of goods, this means to monetarists that the trend of $T$ is a continuum of Walrasian equilibria.

5. The supply of $M$ can be controlled with reasonable precision by the monetary authorities, so that by targeting on an appropriate growth of $\mathrm{M}$, the authorities can control the price level, $\mathrm{P}$, and the rate of inflation.

6. Stable growth of $M$ ensures that price expectations will also be stable and that economic growth will be relatively smooth. 
Differences among monetarists. which account for the protean aspects of the beast. have centred on the first three tenets. There is disagreement on what liquid assets should be included in $\mathrm{M}$. how the demand for money function should be specified, how price expectations are formed. etc. Tenets 4 to 6 . on the other hand. are ideological fixed points. ie. unassailable axioms of faith. rather than testable and potentially rejectable propositions.

We dub them axioms of faith for two basic reasons. The first is that the actual history of both the advanced and the less-developed capitalist economies has been one of cyclically unstable growth. with associated fluctuations in their rates of unemployment and excess capacity. Monetarists explain these fluctuations by ad $h o c$ causal stories of varying plausibility that invariably assign primal responsibility to mismanagement by the monetary authorities. market interferences by the fiscal authorities. or some combination of the two. That is. their empirics are designed to beg rather than answer the question: are tenets 4 to 6 valid? Second. they assume rather than try to prove theoretically that the normal growth path of a competitive market economy with money. debt and capital accumulation. is a continuum of Walrasian general equilibria. They simply ignore the fact that those theorists who have been rigorously exploring the necessary and sufficient conditions for stability of such Walrasian systems have been quite unable to show that non-inflationary full employment growth is one of the general properties |Hahn 1980:1-17|.

There is. nevertheless. a major difference of emphasis between monetarist analysis of the stagflation problems of the advanced capitalist economies and of the Latin American economies. In the former it is assumed that private commodity and financial markets are already adequately competitive so that the solution to stagflation is mainly to correct flaws in macro monetary and fiscal policy. with perhaps a transitory depression to bring wages in union-ridden labour markets in line. In the latter. particularly in the semi-industrialised Latin American countries. monetarists have assumed that the private markets had been badly distorted by the prior mercantilist, labour and social welfare measures used to induce industrial investment and evoke popular backing for the industrialisation effort. Their corrective policy packet has therefore been much more revolutionary. or rather counter-revolutionary. In addition to curbing the growth of $M$ and the fiscal deficit. it includes a wide-ranging set of reforms designed to liberalise commodity and financial markets in order to "get prices right."

'Getting prices right' to its advocates means allowing supply and demand forces to establish a set of relative prices that equate supply with demand in all markets. In real world capitalist economies. however. investors. savers. and lenders make expenditure commitments and enter into debt contracts the profitability of which depends on the future course of relative prices. There is no full set of futures markets in which 'right future prices can be made known at the time the commitments have to be made; nor can there be.' The commitments. on which growth in a capitalist economy depends. have to based on guesses. Equilibrating tendencies in the markets that do exist can be and often are thwarted by cumulative wrong guesses about implicit supply and demand relations in non-existent futures markets. leading to boom/bust patterns of economic growth.

Knowing this. a major part of the entrepreneurial effort of the capitalist firm is devoted to planning and implementing strategies to strengthen its power to influence the future prices and costs relevant for its profitability: by augmenting its technological and mark eting prowess. by vertical and horizontal int egration. by cartel-like understandings with rival firms. etc. When its efforts along these lines are inadequate, the firm is also prone to seek protective governmental measures. Not only is it impossible to get all essential prices right because key markets are lacking. but the search by firms for security by other means results in market structures and prices that are ridden with monopoly elements.

The mercantilistic industrialisation policies of Latin American countries had been premised on the plausible view that the larger. more experienced firms of the advanced capitalist countries were superior along the various dimensions of market power to their incipient Latin American competitors. The 'wrong prices' generated by such policies were in part the obverse of attempts to reduce investor uncertainty by providing protective controls and subsidies as substitutes for the non-existent futures markets. The coherence of the attempts were often undermined by political constraints and mistakes of judgment. providing monetarists with easy and often valid targets of attack. But general liberalisation of commodity and financial markets to get rid of white elephants is like drenching the neighbourhood with DDT to kill mosquitos. The immediate side effects can devastate many other firms as well. while the longer term heritage can be increased uncertainty and a depressed investment climate rather than steady full capacity growth.

Cognisant of the short-term side effects. the Latin American monetarist programmes did incorporate

In the Arrow-Debreu specification of the necessary and sufficient conditions for stability of a Walrasian economy with capital accumulation. money and debt. a complete set of futures markets that produce each day prices for all tomorrows is one of the essentials. 
various measures to ease the transition of firms to the new market environment of 'correct' prices. These variously included phased reductions of import duties, crawling peg exchange rate adjustments, business tax cuts, foreign stabilisation loans to help finance the increased imports and to reduce the strain on domestic money markets of government debt financing. Monetary correction, ie, indexing the nominal value of bank deposits and loans and publicly marketed debt to changes in the price level, was also adopted to assist the transformation of the private financial markets toward 'efficient intermediation' with positive real interest rates. Above all, a central feature of all the programmes was an early and drastic fall in real wages and the wage share of value added.

This last feature was accomplished by exploiting another ambiguity of the 'get prices right' concept. In Walrasian theory alternative sets of equilibrium prices are generated by alternative distributions of income and wealth. Conversely, changing relative prices alters the distribution of value added and the relative values of assets as well as the allocation of economic resources. The 'wrong prices' to the monetarists included subsidised prices of basic foods and some public services such as bus fares that were proportionately much more important in the budgets of the working class than of the more affluent families, as well as 'excessive' prices of import restricted consumables such as motor cars, household durables and various fineries that were predominantly consumed by the middle and upper classes. Operationally, getting prices 'right' meant bringing the relative prices of traded goods in line with international relative prices' and eliminating government subsidies of non-traded public services. This required a relative price twist that depressed the purchasing power of wage income while raising that of the high-salaried and propertied classes. Price level stabilisation required, in turn, dampening reactive money wage pressures and wage-price spiralling.

Monetarist stabilisation efforts in the earlier post-war had foundered on working class reactions and populist political opposition to such unequalising price twists. Reviewing that experience then, I wrote '... that there is always some curtailment of the money supply which will stop inflation ... [ is a] statement ... equally true in theory if the word "wages" were substituted for "money", but in neither form would the advice be very helpful to the perplexed authorities without some correlative estimate of the number of machine guns needed ... to enforce the curtailment' [Felix 1959:584]. In the more recent monetarist programmes of Brazil, Uruguay, Chile and Argentina, machine guns, torture chambers and concentration camps have indeed become standard practice, along with the purging of unions, outlawing of strikes, and suppression of populist and leftist political movements. A brutal, class-ridden, Marxist accumulation model lurks behind the aseptic neoclassical jargon with which Latin American monetarists discourse on stabilisation policy.

However, increasing the surplus by brute force did not translate into a sustained increase in the domestic savings and investment rates. On the contrary, in each of the four countries both the Gross Domestic Savings (GDS) and Gross Domestic Investment (GDI) rates fell after the adoption of monetarism. In Chile and Uruguay the fall was substantial, and as of 1980 neither rate has rebounded to its 1960 s average in the two countries. The drop was milder in Argentina, but only in Brazil did the GDS rate in time regain, and the GDI rate moderately overtake, their respective precoup averages.

Brazil, however, became the partial exception to the rule only after 1968 , when it began bending and discarding some of its monetarist rules. It retained monetary correction and wage repression during the high growth 'miracle' years, 1968-74, but reverted to the pre-coup strategem of lagging the exchange rate adjustments behind the inflation rate as a price dampening device. It abandoned import liberalisation, heavily subsidised 'non-traditional' exports, and promoted the expansion rather than the de-nationalising of major government industrial and financial enterprises. Brazil was also the only one of the four countries to get on a fast growth track for a fairly extended period. Its annual GNP growth during 1968-80, despite deceleration after 1974, exceeded the pre-coup rate. The other three countries fell well short of their respective precoup, pre-monetarist GNP growth rates.

Dazzled by Brazil's fast growth, many outside monetarist observers were slow to recognise the extent of the Brazilian policy heresies. Some gave major credit to Brazil's shift from import substitution to an export promoting trade strategy, although it was Brazil's import/GDP ratio, not its export/GDP ratio, that rose substantially during the post-coup years. Friedman and his disciples attributed much of Brazil's success to the indexing of financial liabilities and claims, which in their view greatly reduced saver and investor uncertainty and markedly improved the efficiency of financial intermediation by Brazil's private capital markets. In fact, indexing favoured the growth of government banks and corporations, since they, not private institutions, could assume indexed liabilities with little risk of insolvency. Indeed, as inflation accelerated after the OPEC price rise, a ceiling well below the ongoing inflation rate had to be imposed on monetary correction to ease the threat of widespread private sector bankruptcy. 


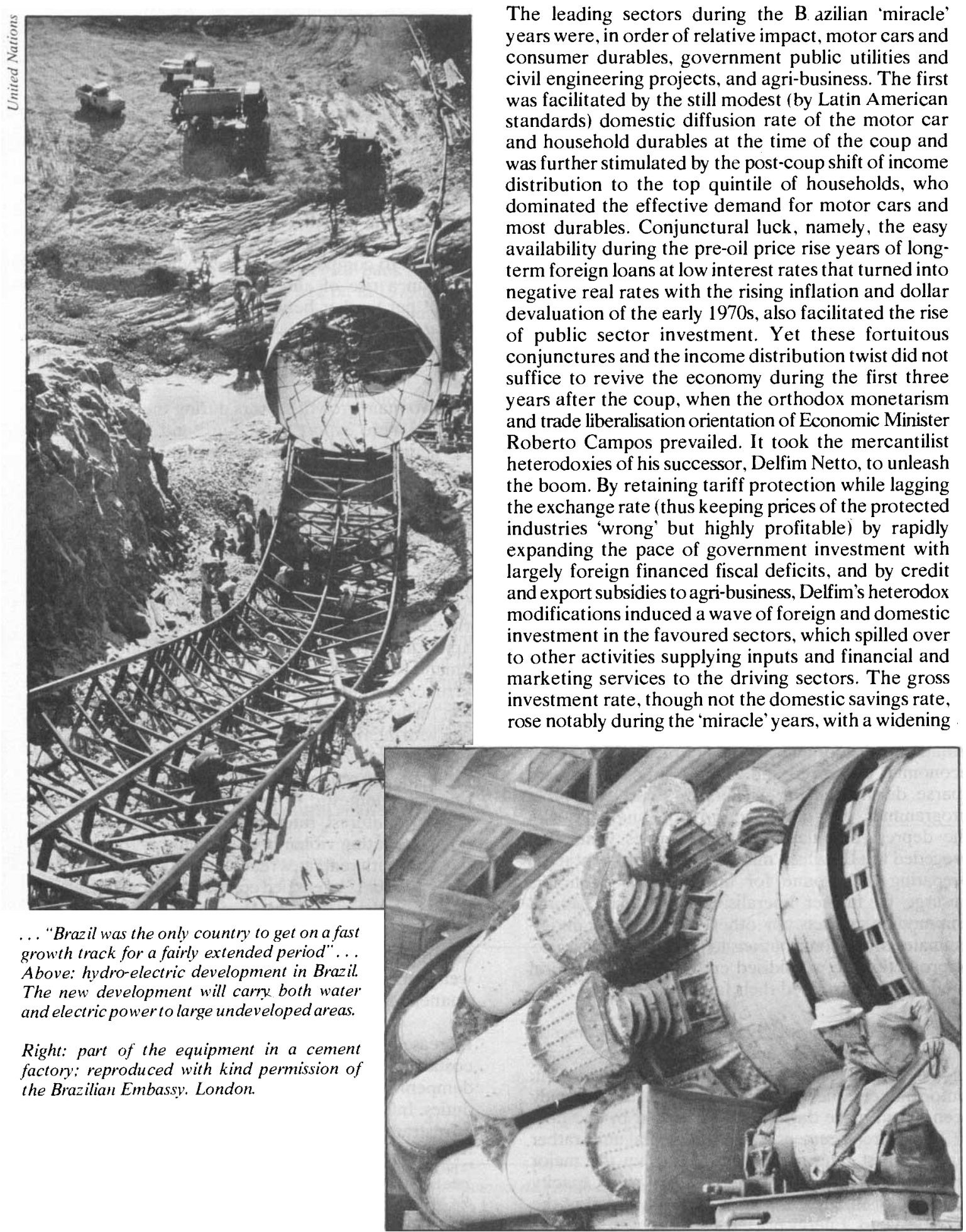


balance of payments deficit on current account making up the difference, while the rate of inflation fell faster than during the preceding period of monetarist orthodoxy.

Had Delfim hit upon a viable formula for fast longterm growth with price stability? Hardly. The oil intensive, technologically dependent economic structure which his strategy fostered was particularly vulnerable to OPEC price rises and changes in the international financial climate. After 1973 fixed interest loans became increasingly sparse, just as Brazil's oil import bill was ballooning from the sharp rise in oil prices. The double impact of a ballooning oil bill and higher cost of credit greatly widened Brazil's chronic current account deficit. Beset by slowing economic growth, rising inflation, a debt-ridden, financially fragile, private sector, reawakened working class militancy and rising middle-class frustration, Delfim's successor teetered ineffectively between policies of monetary constraint and monetary stimulus. In 1979 Delfim returned to office intent on replicating his earlier success; but his second effort has been a resounding failure. Like Mohammed Ali, he should have stayed in retirement.

In sum, monetarism cannot be given prime responsibility for the fact that Brazil's inflation rate now far exceeds the peak rate of the pre-coup era; but neither does it deserve prime credit for the boom years preceding the current breakdown.

Nevertheless, Brazil's miracle years and its success in attracting foreign direct investment and foreign loans strongly influenced the expectations of the monetarist strategists of the other three countries. When their inflation rates remained recalcitrantly high, their economies depressed and foreign direct investment sparse during the early years of their monetarist programmes, they drew comfort from analogies with the depressed, inflation-ridden Campos years that preceded the Brazilian 'miracle' years, and continued preparing the ground for the expected economic upsurge by further liberalising their financial and commodity markets. In other words, gross underestimates of the contributions to the Brazilian 'miracle' of protectionism, subsidised credit and conjunctural good fortune sustained their faith.

Of the three countries, only Argentina had a domestic market for motor cars and consumer durables large enough to attract substantial multinational investment. Unfortunately, most of that investment had already been put in place during the $1960 \mathrm{~s}$, and by the mid1970s, with replacement and supplemental units rather than the first time purchases making up the major share of the market, the profitability of new capacity appeared distinctly lower than it had in Brazil of the 'miracle' years. Energy price rises, moreover, after the initial OPEC rise, darkened the general outlook of the motor car and consumer durable MNCs, and made them more cautious than they had been in the 1960s about expanding in the ldcs. They took advantage of Martinez de Hoz' progressive import liberalisation, therefore, to shift some of their sourcing from Argentina to overseas suppliers and to consolidate Latin American operations, in some cases by shutting down their Argentine plants. More generally, the import liberalisation, which was intended to improve the overall efficiency of the Argentine industrial sector by forcing it to compete more directly with imports, did result in a rise of almost 40 per cent in industrial output per worker between 1976 and 1980 . But this was associated with a 30 per cent fall in industrial employment, a mere five per cent increase in output and a stagnant real volume of industrial investment.

The two main growth sectors during the Martinez de $\mathrm{Hoz}$ era were export agriculture and finance. Until 1979 agriculture benefited from favourable international prices and an exchange policy which closely linked the pace of devaluation to the rate of inflation. The financial sector boomed because of capital market liberalisation, which was carried much further than in Brazil. Interest rate ceilings were abolished as were most restrictions on foreign borrowing by private as well as public firms. The objective was to raise the private savings rate, induce the repatriation of flight capital, and deflect the pressures to accommodate the demand for credit from the Central Bank to the Eurocurrency markets abroad. A two-tiered credit market soon formed. Banks, large industrial and commercial firms with international credit standing, and government entities borrowed heavily in Euro-currency markets, the banks then re-lending at sizeable premia over costs to smaller domestic firms. The oscillating negative real bank interest rates of the pre-monetarist era, began oscillating violently and mainly in the positive quadrant, with real rates reaching peaks of $40-60$ per cent per annum. ${ }^{2}$ Intensified competition from liberalised imports and from the large firms with direct access to cheaper foreign credit drove many smaller firms toward bankruptcy. Flushed with profits from their credit arbitraging, a number of private banks collected debtweakened firms on the cheap and ballooned into large financial-industrial and commercial conglomerates.

Increased market concentration, rapidly rising interest costs, and frequent devaluation more than offset the dampening effect of falling real wages and import duties. Inflation stayed in the three-digit range, leading a frustrated Martinez de $\mathrm{Hoz}$ to revert after 1979 to

\footnotetext{
${ }^{2}$ The oscillations reflected in part the degree of lag of the exchange rate behind domestic inflation. Increasing the lag tended to pull down the short-term real interest rate, but eliminating the lag stimulated the inflation rate so that the monetary authorities were in a catch-22' situation [ Frenkel 1980:213-48].
} 
the traditional Latino strategem of lagging the exchange devaluations well behind the inflation rate. That rate decelerated to lower three-digit figures, but at the cost of an intensifying profit squeeze on export agriculture and import-competing industrial firms. Foreign borrowing to meet cash-flow shortfalls accelerated, as did the growth of the current account deficit and the foreign debt. In 1980 some of the leading private banks and conglomerates were forced into bankruptcy by rising Euro-currency rates abroad and mounting loan defaults at home. The spreading financial crisis set off panic flight from the peso. Central bank reserves dropped from a peak of almost $\$ 12$ bn in 1979 to less than $\$ 4$ bn by the end of 1980 . More rapid devaluation, reintroduced to staunch the flight, merely accelerated the inflation rate. By mid-1981 Martinez de Hoz' hapless successor was confronted with a $\$ 30$ bn foreign debt, $\$ 1$ bn in reserves, inflation approaching 200 per cent and rapidly declining industrial output and employment.

The implementing of Chile's monetarist strategy has differed in three main respects from Argentina's. First, it has succeeded in carrying through a drastic sell-off of public enterprises, a feat Martinez de $\mathrm{Hoz}$ was unable to accomplish, primarily because in contrast to Chile's, the Argentine armed forces have long controlled and operated a wide, untouchable array of public sector firms. Second, the removal of unions from policy influence was more complete in Chile than in Argentina, allowing the Chilean Chicago Boys a virtual free hand to gut social programmes and to privatise much of the public health, pension and even educational institutions. All this has enabled the Chilean monetarists to reduce greatly the public sector's share of GDP and to eliminate the fiscal deficit by 1979 ; achievements which exceeded Martinez de Hoz' grasp. Third, the Chilean monetarists were able to brush aside industrialist resistance to import liberalisation and to bring down import tariffs by 1979 to a maximum rate of 10 per cent, except for automobiles .

The 'dual' of these accomplishments was a deeper and more prolonged drop in real output and employment than in Brazil under Campos or Argentina under Martinez de Hoz. Not until 1980 did Chile's GDP per capita rebound almost to the 1972 Allende level. In 1980 the Gross Domestic Investment rate was still below their respective late 1960s levels, while the Gross Domestic Savings rate, despite the twist toward greater income concentration, was far lower. The unemployment rate was far higher than their 1960s averages. Despite the opening up of the Chilean economy and the well-publicised rise of non-traditional exports, the real value of Chilean exports in 1978 was 10 per cent below that of 1970 , although real imports were 38 per cent higher. Motor cars, household durables, luxury goods, beverages and clothing, and petroleum dominated the increase in real imports; imports of capital goods and industrial intermediates rose negligibly, despite the decline in competing domestic production [Ffrench-Davies 1979].

The changes in the sectoral shares of output and employment shown in Table 1 suggest the extent to which the recovery of GDP was governed by trade and financial liberalisation. The share of commerce in GDP as 7.1 per cent higher, and its share of employment

Sectoral shares of GDP and employment in Chile 1970-78

\begin{tabular}{|c|c|c|c|c|c|c|c|}
\hline & & \multicolumn{2}{|c|}{1970} & \multicolumn{2}{|c|}{1978} & \multicolumn{2}{|c|}{$\begin{array}{c}\text { per cent change, } \\
1970-78\end{array}$} \\
\hline & & $\begin{array}{l}\text { output } \\
\text { share }\end{array}$ & $\begin{array}{c}\text { employment } \\
\text { share }\end{array}$ & $\begin{array}{l}\text { output } \\
\text { share }\end{array}$ & $\begin{array}{c}\text { employment } \\
\text { share }\end{array}$ & output & employment \\
\hline I. & $\begin{array}{l}\text { goods sectors } \\
\text { (agriculture, } \\
\text { mining industry, } \\
\text { construction) }\end{array}$ & .514 & .526 & .477 & .415 & -7.2 & -21.1 \\
\hline II. & $\begin{array}{l}\text { energy and } \\
\text { transportation }\end{array}$ & .064 & .063 & .068 & .073 & +6.2 & +15.9 \\
\hline III. & $\begin{array}{l}\text { commerce and } \\
\text { services }\end{array}$ & .422 & .411 & .452 & .508 & +7.1 & +23.6 \\
\hline
\end{tabular}

Source: ODEPLAN, Cuentas Nacionales, INE Encuesta Nacional de Empleo, as cited in Carlos Filgueira, Acerca del consumo en los nuevos modelos Latinoamericanos' Naciones Unidas, Comision Economica para America Latina, Santiago. 28 May, 1981, E/CEPAL/R.261, mimeo. 
23.6 per cent higher in 1978 than in 1970 . Conversely, the output and employment shares of the goods producing sectors fell 7.2 per cent and 21.1 per cent, respectively. 'Getting prices right' pushed the increase of labour productivity in the goods producing sectors above the national average, but mainly by depressing employment more than output. It increased the output share of commerce and services primarily by raising the profitability of financial, marketing and importing activities, but reduced overall output per worker in commerce and services by swelling the so-called 'informal sector' with workers rejected by the goods producing activities.

As in Argentina, financial liberalisation created a twotiered credit market and an explosive growth of conglomerates. This growth, assisted further by the selling off of public sector assets at low prices, and the alienation of small-holdings to agri-business combines following the revoking of land reform legislation, was carried much further than in Argentina. In 1978 the two largest conglomerates (Cruzat and Vial) controlled half the corporate capital registered on the Chilean stock exchange. With the demise of Somoza's Nicaraguan empire, Chile now probably has the highest private concentration of ownership in Latin America. As in Argentina, the monetarist strategy also had considerable difficulty in bringing inflation below three digits. By 1977, however, that feat was accomplished, and by early 1981 the rate was falling below 30 per cent per annum, approaching Brazil's 1972 minimum.

Where then is the Achilles heel? Partly it lies in the low investment rate and flabby productive structure beneath the glittering facade of ostentatious import-intensive consumerism and financial wheeling and dealing. Mainly, it is the rapid increase of foreign indebtedness and the widening current account deficits that have been sustaining that façade.

Gross foreign debt more than doubled between 1977 and 1980, equalling 2.3 times export receipts in 1980 . The debt structure has also become more precarious: its average maturity has declined by about 40 per cent since 1976. The proportion of the debt consisting of private liabilities without government guarantee rose to 55 per cent in 1980 and virtually all of the public and private debt has been transformed into interest-adjustable Euro-currency obligations. By 1980 Chile led Latin America debtor countries in the ratios of debt-service to exports and debt to GNP.

The rising foreign debt has financed Chile's widening current account deficit, which in 1978 already averaged 8 per cent of GDP. In 1981, because of rapidly rising LIBOR rates, falling copper prices and depressed world markets for Chile's timber based exports, the deficit is projected by one of Chile's Chicagoid economic pundits to rise to 10 or 11 per cent of GDP |Fontaine 1981|. Recent reports indicate a dramatic increase in the trade deficit in the first half of 1981.

Chile's Chicago Boys, nevertheless, remain cock-ahoop about riding out the storm. In a seminar for visiting bankers in May 1981, Central Bank presidents past and present were mobilised to reassure the visitors that because the rising debt was being incurred by the private sector it could never be excessive, as it represented resources that would always be used productively. Nor was the current account deficit-a danger, since it was only a reflex of private borrowing and would fall automatically if the profitability of private investment declined. Moreover, Central Bank foreign reserves totalled about 30 per cent of the foreign debt, which gave ample scope for handling transitory adjustment problems |Ercilla 1981|. How the bankers reacted to this arrantly naive textbook monetarism is not reported, but we do know that in 1979 Chile had already been placed 40th among 75 debtor countries in degree of country risk |Euromoney 1980 l.

In fact, Chile's monetarist strategy has trapped itself in an impending 'catch-22' type financial bind. Most of the peso debt in the two-tiered credit market is indexed to the exchange rate. Since 1977 the authorities have been lagging that rate well behind the inflation rate, and after June 1979 went on to freeze it to the dollar. This has helped lower the inflation rate and the threat to the solvency of local firms from massive revaluation of their peso debt. The obverse side has been an increasing overvaluation of the exchange rate, estimated at perhaps 40 per cent in 1981 relative to 1977 . Combined with tariff liberalisation, the exchange policy has ballooned imports and, by 1980, was imposing a severe price-cost squeeze on non-traditional exports. This, however, accounts for only part of the widening current account deficit, since by 1980 debt servicing had become the more important factor, as Chile entered the explosive Ponzi phase of indebtedness, to use Hyman Minsky's terminology, in which new debt is required in order to service old debt. The choice now is essentially how the Government of Chile wants the financial crisis to come. One way would be to devalue, the resulting revaluation of the indexed peso debt setting off a wave of bankruptcies and a financial panic à la Argentina. A second is to hold the exchange rate while squeezing hard on the supply of domestic credit; in effect depressing the activity level in order to staunch the demand for imports. In this case the financial panic could come from widespread defaults on domestic peso loans and from their negative feedback. on the ability of the conglomerates to service their foreign debt. Finally, the monetary authorities could try to halt the financial crunch by bailout credits requiring an upsurge of the money supply. This might 
or might not ease the bankruptcy threat, but it could certainly turn the inflation rate rapidly upward and destroy the Chicago Boys' main claim to success. As for Chilean foreign reserves providing an adequate safety net against any of these eventualities, it should be noted that the foreign reserves/foreign debt ratio of Argentina in 1979 was much higher than Chile's in 1981. Capital flight in Latin America can take off with amazing speed and power.

The theme of this essay resembles the Irish drinking song: 'Shut the door, they're coming through the window! Shut the window, they're coming through the door!'The theoretical flaws of monetarism will eventually show up in any application. Applied to Latin American countries with their technological dependence, avid import-intensive consumerism, gross income inequalities and weak social cohesion, the flaws magnify in the execution. This does not mean that given these characteristics there are easily applicable alternative st rategies for reconciling growth with equity and price stability. Perhaps the most basic charge against Latin American monetarism is not failure but moral turpitude. It is a strategy that exacerbates many of the above traits, but its recent applicants have been willing to accept greatly raising the level of brutality and inhumanity in countries that less than two decades ago seemed to be outgrowing such behaviour.

\section{References}

Ascheim, J., and G. S. Tavlas, 1979, 'On monetarism and ideology', Banca Nazionale del Lavoro Quarterly Review, no 129, June

Ercilla, 3 Junio, 1981

Euromoney, February, 1980

Felix, David, 1959, 'Industrialisation and stabilisation dilemmas in Latin America, Journal of Economic History, XIX, December

Ffrench-Davies, Ricardo, 1979, 'Politicas de comercio exterior en Chile: 1973-1978', CIEPLAN, Santiago, November, mimeo

Fontaine, Juan Andres, 1981, 'El momento economico y sus proyecciones', Ercilla: Economico. May

Frenkel, Roberto, 1980, 'El desarrollo reciente del mercado de capitales en la Argentina, Desarrollo Economico, vol 20 no 78 , Julio-Setiembre

Hahn, F. H., 1980, 'Monetarism and economic theory', Economica. vol 47 , February 